\title{
DIAGNOSIS OF POTATO VIRUSES IN KAZAKHSTAN: MOLECULAR CHARACTERISATION OF ISOLATES
}

\author{
Karpova O.V. ${ }^{1}$, Alexandrova A.M. ${ }^{1}$, Nargilova R.M. ${ }^{1}$, Kryldakov R.V. ${ }^{1}$, \\ Yekaterinskaya E.M. ${ }^{2}$, Romadanova N.V. ${ }^{3}$, Kushnarenko S.V. ${ }^{3}$, Iskakov B.K. ${ }^{1}$ \\ ${ }^{1}$ Institute of Molecular Biology and Biochemistry named after M.A.Ajtkhozhin, \\ Dosmukhamedov str. 80, Almaty, 050012, Kazakhstan \\ ${ }^{2}$ Kostanay State University named after A.Baytursynov, \\ Baytursynov str. 47, Kostanay, 110005, Kazakhstan \\ ${ }^{3}$ Institute of Plant Biology and Biotechnology, \\ Timiryazev str. 45, Almaty, 050040, Kazakhstan \\ oxkarpova@mail.ru
}

\section{ABSTRACT}

Virus infection is one of the reasons for the low potato yield in Kazakhstan. The combination of modern methods of germplasm improvement and effective virus diagnosis are the most successful measures to overcome potato viruses. Using ELISA and multiplex RT-PCR methods, potato leaf samples from the Almaty and Kostanay regions of Kazakhstan were analysed for the presence of the carlaviruses potato virus $M$ and potato virus $S$, the potyvirus potato virus $Y$, the potexvirus potato virus $X$, and the polerovirus potato leaf roll virus (PVM, PVS, PVY, PVX, and PLRV, respectively). The potato virus spectrum has changed over the last twenty years, and presently carlaviruses represent the most widespread genus. Of the leaf samples tested, $84.3 \%$ and $46.6 \%$ were infected by PVM and PVS, respectively, and co-infection by both viruses occurred. Multiplex RT-PCR assays were developed to detect the five potato viruses, and for two strains of PVS. Based on sequence analyses of the central region of the capsid protein, fourteen Kazakh PVS isolates were identified, of which eleven were classified as the 'ordinary' strain, and three as 'Andean' strains. Our findings confirmed the existence of divergent PVS strains with different origins present in Kazakhstan.

Key words: potato, carlaviruses, potato virus S, capsid protein, diagnosis.

\section{INTRODUCTION}

Potato is one of the most important food crops in the world and the second ware product after wheat in Republic of Kazakhstan. The grade degeneration and pathogen organisms including viruses are the main reasons of low potato productivity in Asia. Potato is affected by more than 40 viruses, some of which occur worldwide, the others are restricted to a certain geographical region [1,2]. Virus diseases reduce yield on the average of $30-50 \%$ and moreover at the several reproductions. Spread of virus infection depends on variety's traits and the phase of plant development. The most affected plants have been recorded for cultivars with early or middle phases of maturation. 
Potato viruses cause the mottled, rugose, stripe or "gothic" mosaic and leaf deformation such as rolling, crinkling, curling and twisting [1, 2, 3]. However, as it was shown by serological analysis, the significant quantity of externally healthy plants can be infected by Potato virus X (PVX, genus Potexvirus, family Alphaflexiviridae), Potato virus Y (PVY, genus Potyvirus, family Potyviridae), Potato virus M (PVM, genus Carlavirus, family Betaflexiviridae), Potato virus S (PVS, genus Carlavirus, family Betaflexiviridae) or Potato leaf roll virus (PLRV, genus Luteovirus, family Luteoviridae). Contamination can be caused by single virus or the combination of several viruses. All these viruses can be transmitted by mechanical means and nonpersistent manner by aphids, such as Aphid fabae, A. nasturtii, Myzus persicae and/or by infected seed tubers [1].

The creation of resistant cultivars by the traditional methods of breeding, the control of secondary infection and usage of virus free seed tubers are the main directions of the plant virus protection. The combination of planting material improvement methods and diagnostic methods of molecular biology helps to prevent the transmission of the secondary infection into the fields. Serological techniques, in particular, the enzyme-linked immunosorbent assay (ELISA), and the more sensitive procedure, for example, the reverse transcription polymerase chain reaction (RT-PCR) has been widely employed for detection and identification of potato viruses [4-6].

PVS is a member of the Carlavirus genus, family Betaflexiviridae and infects plants belonging to Solanaceae and Chenopodiaceae families [1, 3]. PVS has been classified as two strains, PVS $^{\mathrm{O}}$ (Ordinary) and PVS $^{\mathrm{A}}$ (Andean), depending on their ability to induce non-systemic and systemic infection in Chenopodium spp., respectively [7]. It was found that $\mathrm{PVS}^{\mathrm{O}}$ and $\mathrm{PVS}^{\mathrm{A}}$ have significant differences in nucleotide sequence of gRNAs [8, 9]. More often, PVS causes symptom of less infection in most potato cultivars, although severe symptoms, such as slight deepening of veins, rugosity of leaves, weak mosaic or bronzing may lead to forming of necrotic spots and plant stunting [1,2]. This virus reduce yield by $10-15 \%$ and PVS co-infection enhances the severity of other virus symptoms.

PVS genomic RNA (gRNA) is a capped single-stranded positive-sense mRNA of approximately $8.5 \mathrm{~kb}$ in length with a poly(A)-tail at the 3'-terminus [8-12]. This gRNA has six open reading frames (ORFs). ORF1 encodes polypeptide of about $223 \mathrm{kDa}$ $(223 \mathrm{~K})$ containing the coding sequences of methyltransferase, helicase and RNAdepending RNA polymerase. ORF2, ORF3 and ORF4 encode the proteins $25 \mathrm{~K}, 12 \mathrm{~K}$ and $7 \mathrm{~K}$ constituted the triple gene block (TGB) specific for all carlaviruses [10]. These proteins are involved in cell-to-cell movement and have high homology with the regions of the potexvirus genome. ORF5 corresponds to a capsid protein (CP) of about $34 \mathrm{~K}$ which has the most conservative sequence with $59 \%$ homology to potexvirus CP [11]. ORF6 encodes cysteine-rich nucleic-acid-binding protein (NABP) of about $11 \mathrm{~K}$.

PVS forms two sub-genomic RNAs in length of $2.5 \mathrm{~kb}$ and $1.5 \mathrm{~kb}$, which encode the proteins of TGB and CP plus $11 \mathrm{~K}$-protein respectively [8]. Using cluster analysis it was shown several differences in amino acid sequences between $\mathrm{PVS}^{\mathrm{O}}$ and $\operatorname{PVS}^{\mathrm{A}}[5,6$ 12].

Both $\mathrm{PVS}^{\mathrm{O}}$ и $\mathrm{PVS}^{\mathrm{A}}$ strains were found in potato seed in East Kazakhstan in 2017 [13]. However, no information was received on the distribution of various strains in the fields of the northern and southern regions of the Republic of Kazakhstan.

Here, we report a standardized multiplex RT-PCR (mpRT-PCR) protocol that has proven to be effective in detecting of five potato viruses (PVX, PVM, PVY, PVS and PLRV) simultaneously. The aim of our work was to study the spread of viruses in the main potato-growing regions of Kazakhstan. Our study led to the detection of two PVS strains in Kazakhstan by this sensitive method proved by double antibody 
sandwich enzyme-linked immunosorbent assay (DAS-ELISA) and comparative analysis of partial coding sequence of PVS CP.

\section{Materials and methods}

\section{Plant material}

All samples were collected randomly as naturally virus infected or control noninfected potato (Solanum tuberosum L.). Our collaborators from Kazakh Research Institute of Potato and Vegetable Farming and Kostanay Agriculture Research Institute kindly provided potato tubers and leaf samples respectively. In the first case we analyzed sprouted tubers of 45 cultivars (78 samples) brought from Almaty region, the south part of Kazakhstan. In the second case, leaf samples were taken of 27 cultivars (171 samples) from northern fields in Kostanay region. In general, leaves and tubers were collected in August and at the end of September respectively.

\section{ELISA}

Potato leaves were tested for PVX, PVY, PVM, PVS and PLRV infection by DAS-ELISA using the kits "BIOREBA" (Switzerland). The $405 \mathrm{~nm}$ values were recorded using a plate reader (model Stat Fax-2100, "Awareness Technology", USA). Samples were considered positive if the absorbance values were high than the value of corresponding negative control and higher than 0.1 after incubation for $1 \mathrm{~h}$ at room temperature. Assay for each sample was carried out at least three times.

\section{RNA Extraction and multiplex RT-PCR (mpRT-PCR)}

Total RNAs were extracted from fresh or frozen leaves (0.5-1.0 g) using TRIzol reagent ("Sigma-Aldrich", USA) according to the manufacture's instruction. The pellets were dissolved in $100 \mu 1$ RNase-free water.

First-strand complementary DNA (cDNA) was synthesized using $5 \mu \mathrm{g}$ of total RNA, an oligo $(\mathrm{dT})_{18}$ as reverse primer at 100 pmol final concentration, Maxima (Moloney murine leukemia virus) Reverse Transcriptase and reaction buffer ("Thermo Fisher Scientific", Lithuania) with final reaction volume as $30 \mu 1$. Synthesized cDNA was amplified using Taq DNA polymerase and its buffer system ("Thermo Fisher Scientific", Lithuania) using the primers targeting CP regions of PVX, PVS, PVY, PVM and PLRV which were published earlier [4] (Table 1). PCR was carried out in volume of $25 \mu \mathrm{l}$ using $2.5 \mu \mathrm{l} \mathrm{cDNA}$ and five primer pairs at final concentration of 2 pmol. The PCR program consisted of $5 \mathrm{~min}$ at $94{ }^{\circ} \mathrm{C}, 30$ cycles of $30 \mathrm{~s}$ at $94{ }^{\circ} \mathrm{C}, 30 \mathrm{~s}$ at $57^{\circ} \mathrm{C}, 1 \mathrm{~min}$ at $72{ }^{\circ} \mathrm{C}$ followed by the final extension for $5 \mathrm{~min}$ at $72{ }^{\circ} \mathrm{C}$ in Gene Amp PCR System 9700 ("Applied Biosystems"). PCR products were analyzed in $2 \%$ agarose gel. New set of primers was designed for PVS to detect the variation among them.

\section{Sequence analysis and phylogenetic relationship}

For sequence analysis PCR was carried out in $50 \mu 1$ using one pair primers specific for PVS (\#PVS-Forward, \#PVS-Reverse, \#PVS-CP-Forward or \#PVS-CPReverse), Pwo-polymerase ("Roche Applied Science", Germany) and the same reaction conditions. Then the amplified DNA products were purified from agarose gels using Gene JET Gel Extraction kit ("Thermo Fisher Scientific", Lithuania) according manufacturer's instructions. Finally, DNAs were eluted by $50 \mu 1 \mathrm{de}$-ionized sterile water for each sample.

For sequencing the samples were prepared in $10 \mu 1$ reaction mixes contained of 150-400 ng pure DNA, 1x buffer for sequencing ("Applied Biosystems"), 1x Big Dye Terminator v. 3.1 ("Applied Biosystems") and $1 \mu \mathrm{M}$ forward or reverse primer. The PCR program consisted of $2 \mathrm{~min}$ at $94{ }^{\circ} \mathrm{C}, 25$ cycles of $10 \mathrm{~s}$ at $94{ }^{\circ} \mathrm{C}, 5 \mathrm{~s}$ at $50{ }^{\circ} \mathrm{C}, 4 \mathrm{~min}$ 
at $60{ }^{\circ} \mathrm{C}$. Products of sequencing were purified using columns Centri-Sep according protocol of Princeton Separations (USA). Then the samples were desiccated of water, denaturized $5 \mathrm{~min}$ at $95{ }^{\circ} \mathrm{C}$ in $15 \mu \mathrm{Hi}$-Di formamide and were put in $\mathrm{ABI}$ Genetic Analyzer 310 ("Applied Biosystems"). Sequencing analysis was provided twice into two directions for each sample. Computer analysis of nucleic and amino acid sequences was performed using such programs as DNAMAN version 5.2 and SEQUENCING ANALYSIS version 5.2. BLAST (at www.ncbi.nlm.nih.gov/BLAST) was used to compare the new DNA sequence of each PVS gene fragment with the sequences from NCBI GenBank database.

Multiple alignments and phylogenetic analysis were achieved using the MEGA $\mathrm{X}$ software [14]. The phylogenetic tree was constructed with the Neighbor-Joining method [15]. The percentage of replicate trees in which the associated taxa clustered together in the bootstrap test (2000 replicates) are shown next to the branches [16]. The evolutionary distances were computed using the Kimura 2-parameter method [17].

\section{RESULTS AND DISCUSSION}

\section{Virus detection by ELISA}

The last surveys of potato viruses in south and north of Kazakhstan were carried out twenty years ago in which PVS and PVY were reported as the main viruses based on ELIS A of potato samples taken from Almaty, Zhambyl and Akmola Kazakh regions The percentage of plants infected by these viruses was high in 1996 in the Almaty region (PVS from 57 to $100 \%$, and PVY from 64 to $100 \%$, depending of cultivars). Apart from these two viruses, PVX (no more than 35\%), PVM (32-85\%) were also found in southern farms. PLRV infection was reported at $20 \%$ and $39 \%$ only for two cultivars. Whereas in the Akmola region a low percentage (from 3 to 14.2\%) of infection is noted for all five variants of viruses [18].

However, in the current study of the 249 samples collected from Almaty and Kostanay Kazakh regions and tested by DAS-ELISA, in $85.5 \%$ of them the viruses were detected. PVY and PVX were identified as minor viruses (table 2).

Table 2. Single and mixed virus prevalence in potato accessions

\begin{tabular}{|c|c|c|}
\hline Virus & $\begin{array}{l}\text { Numbers of plants } \\
\text { infected by virus }\end{array}$ & Infection level (\%) \\
\hline \multicolumn{3}{|c|}{ Single infection: } \\
\hline PVM & 80 & 32.1 \\
\hline PVS & 0 & 0 \\
\hline PVY & 1 & 0.4 \\
\hline PVX & 0 & 0 \\
\hline PLRV & 0 & 0 \\
\hline \multicolumn{3}{|c|}{ Mixed infection: } \\
\hline $\mathrm{PVM}+\mathrm{PVS}$ & 101 & 40.6 \\
\hline PVM+PVX & 5 & 2.0 \\
\hline PVM+PVY & 9 & 3.6 \\
\hline $\mathrm{PVS}+\mathrm{PVY}$ & 2 & 0.8 \\
\hline $\mathrm{PVM}+\mathrm{PVS}+\mathrm{PVY}$ & 10 & 4.0 \\
\hline $\mathrm{PVM}+\mathrm{PVS}+\mathrm{PVX}$ & 3 & 1.2 \\
\hline $\mathrm{PVM}+\mathrm{PVX}+\mathrm{PVY}$ & 1 & 0.4 \\
\hline PVM+PVY+PLRV & 1 & 0.4 \\
\hline In total: & 213 & 85.5 \\
\hline \multicolumn{3}{|c|}{ Total separate virus prevalence: } \\
\hline PVM & 210 & 84.3 \\
\hline
\end{tabular}




\begin{tabular}{|l|c|c|}
\hline PVS & 116 & 46.6 \\
\hline PVY & 24 & 9.6 \\
\hline PVX & 9 & 3.6 \\
\hline PLRV & 1 & 0.4 \\
\hline
\end{tabular}

The percentage of PVS infection slightly decreased to $46.6 \%$, whereas level of PVM infection reached to $84.3 \%$. Although PVM was a dominant virus on the territory of Kazakhstan, mainly potato was contaminated by both PVM and PVS. The highest coinfection (40.6\%) was observed between PVM and PVS followed by PVM and PVY $(3.6 \%)$. In case of triple virus mixed infections, the highest incidence $(4.0 \%)$ was found for PVM, PVS and PVY followed by PVM, PVS and PVX (1.2\%). The percentage of co-infection of PLRV, PVM and PVY was equivalent with PVM, PVX plus PVY coinfection $(0.4 \%)$. Usually mixed infection induces much more severe foliar symptoms than single virus disease and leads to more rapid lethal outcome for plants.

The climate of Kostanay region is much more favorable for potato growing than the south of Kazakhstan. 18.7\% and 3.8\% of samples respectively were free of viruses. In southern regions with dry and hot summer the massive spread of aphids are observed usually twice during season in June and in August. Unlike in the south, the absence of rains in the first half of June and heavy rainfall in late July and early August led to a shift in the growth and development of potato plants and to the large-scale the death of larvae in the Kostanay region in 2015 [19]. Two Kostanay's cultivars Udovitskiy and Dunyasha were compared for virus resistance. The first one, late-maturation cv. Udovitskiy, was less susceptible for virus infection. Only 13 samples of 42 (30.9\%) were shown to contain viruses including 10 plants hit by PVM and 3 plants infected PVM+PVS. Only one plant of 50 samples Dunyasha was free of viruses.

\section{Development of multiplex RT-PCR and its application to virus detection}

mpRT-PCR can be challenging task to develop a suitable set of compatible primers and differentiating of various amplicons.

RNAs prepared from leaves of positive controls (PVX, PVM, PVY, PVS or PLRV) were reverse transcribed either separately or in a pool of all five genomes. Discrete virus specific bands were detected from both cDNA sources and the cDNA pool of all viruses in the uni- or multiplex RT-PCR (Fig. 1, lanes 1-6 and 7-12, 17-27). 

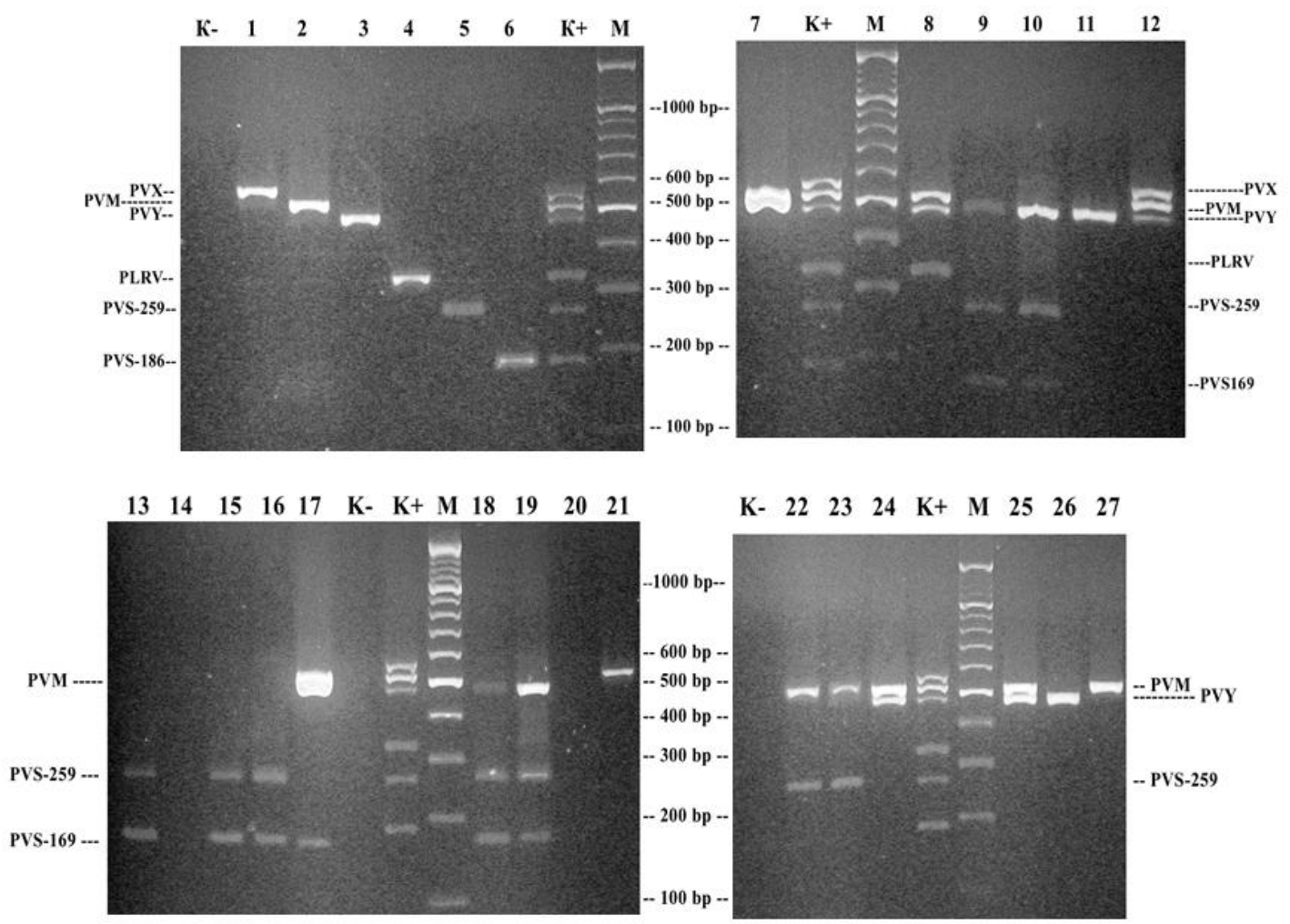

Lanes 1-6 - uniplex RT-PCR for PVX (lane 1), PVM (lane 2), PVY (lane 3), PLRV (lane 4), PVS (lanes 5 and 6), "K-" - negative control, "K+" - positive control, M - marker (GeneRulerTM 100 bp), lanes 7-12, 17-27 - mpRT-PCR for PVX, PVM, PVY, PLRV and PVS, lanes 13-16 - duplex RT-PCR for PVS.

Positions of marker bands were placed in centre, positions of virus-specific bands were indicated on the right or on the left.

Fig. 1. Agarose gel electrophoresis of RT-PCR products of PVX, PVM, PVY, PLRV and PVS infected leaves (total RNA extract).

PVX-, PVM-, PVY-, PLRV- and PVS-specific primers (table 1) produced bands of $562,520,480,336$ and 186 bp respectively as for the each positive control as for singly or plural infected samples. Only one PLRV-infected plant was detected (figure 1, lane 8).

Table 1. Nucleotide sequences of primers used for mpRT-PCR and sequencing

\begin{tabular}{|c|c|c|c|c|c|}
\hline № & Primer names & $\begin{array}{l}\text { Genome } \\
\text { position }\end{array}$ & $\begin{array}{c}\text { Full nucleotide } \\
\text { sequences }\end{array}$ & $\begin{array}{c}\text { Fragmen } \\
\text { t size } \\
\text { (bp) }\end{array}$ & $\begin{array}{l}\text { Refer } \\
\text { ences }\end{array}$ \\
\hline \multirow[t]{2}{*}{1} & \#PVX - Forward & $5664-5683$ & $\begin{array}{l}5^{\prime}-\text { tagcacaaca } \\
\text { caggccacag }-3\end{array}$ & \multirow[t]{2}{*}{562} & \multirow[t]{2}{*}{ [4] } \\
\hline & \#PVX - Reverse & $6205-6225$ & $\begin{array}{l}5-\text { ggcagcattc } \\
\text { atttcagctt c }-3\end{array}$ & & \\
\hline \multirow[t]{2}{*}{2} & \#PVY - Forward & $8723-8742$ & $\begin{array}{l}5^{\prime}-\text { acgtccaaaa } \\
\text { tgagaatgcc }-3,\end{array}$ & \multirow[t]{2}{*}{480} & \multirow[t]{2}{*}{ [4] } \\
\hline & \#PVY - Reverse & $9183-9202$ & $\begin{array}{l}5^{\prime}-\text { tggtgttcgt } \\
\text { gatgtgacct }-3,\end{array}$ & & \\
\hline \multirow[t]{2}{*}{3} & \#PVM - Forward & $7242-7264$ & $\begin{array}{l}5,- \text { gaaagctgaa } \\
\text { actgccaaag atg }-3,\end{array}$ & \multirow[t]{2}{*}{521} & \multirow[t]{2}{*}[23]{} \\
\hline & \#PVM - Reverse & $7737-7762$ & $\begin{array}{l}5,- \text { catctgcagt } \\
\text { tatagcacct cttgg }-3\end{array}$ & & \\
\hline \multirow[t]{2}{*}{4} & \#PLRV - Forward & $3653-3672$ & $\begin{array}{l}5^{\prime}-\text { cgcgctaaca } \\
\text { gagttcagcc }-3,\end{array}$ & \multirow[t]{2}{*}{336} & \multirow[t]{2}{*}[4]{} \\
\hline & \#PLRV - Reverse & 3969-3988 & 5'-gcaatggggg & & \\
\hline
\end{tabular}




\begin{tabular}{|c|c|c|c|c|c|}
\hline & & & tccaactcat $-3^{\prime}$ & & \\
\hline \multirow[t]{2}{*}{5} & \#PVS - Forward & $7547-7566$ & $\begin{array}{l}5^{\prime}-\text { tggcgaacac } \\
\text { cgagcaaatg }-3,\end{array}$ & \multirow[t]{2}{*}{186} & \multirow[t]{2}{*}{ [24] } \\
\hline & \#PVS - Reverse & $7711-7732$ & $\begin{array}{l}5 \text { ' - atgatcgagt } \\
\text { ccaagggcac tg }-3,\end{array}$ & & \\
\hline \multirow[t]{2}{*}{6} & \#PVS-CP-Forward & $7216-7235$ & $\begin{array}{l}5^{\prime}-\operatorname{atgccgccca} \\
\text { aaccggatcc }-3,\end{array}$ & \multirow[t]{2}{*}{885} & \multirow[t]{2}{*}{$\begin{array}{l}\text { This } \\
\text { paper }\end{array}$} \\
\hline & \#PVS-CP-Reverse & $8078-8100$ & $\begin{array}{l}5^{\prime}-\text { tcattggttg } \\
\text { atcgcattac ggt }-3,\end{array}$ & & \\
\hline \multirow[t]{2}{*}{7} & $\begin{array}{l}\text { \#PVS-new- } \\
\text { Forward }\end{array}$ & $7457-7477$ & $\begin{array}{l}5^{\prime}-\text { atgaaatgcg } \\
\text { gaggaatccg g-3, }\end{array}$ & \multirow[t]{2}{*}{259} & \multirow[t]{2}{*}{$\begin{array}{l}\text { This } \\
\text { paper }\end{array}$} \\
\hline & $\begin{array}{l}\text { \#PVS-new- } \\
\text { Reverse }\end{array}$ & $7690-7715$ & $\begin{array}{l}5^{\prime}-\text { actgctccag } \\
\text { ttgggaactc aacagt }-3,\end{array}$ & & \\
\hline \multirow[t]{2}{*}{8} & \#PVS - Forward & $7547-7566$ & $\begin{array}{l}5^{\prime}-\text { tggcgaacac } \\
\text { cgagcaaatg }-3,\end{array}$ & \multirow[t]{2}{*}{169} & {$[24]$} \\
\hline & $\begin{array}{l}\text { \#PVS-new- } \\
\text { Reverse }\end{array}$ & $7690-7715$ & $\begin{array}{l}5^{\prime}-\text { actgctccag } \\
\text { ttgggaactc aacagt }-3,\end{array}$ & & $\begin{array}{l}\text { This } \\
\text { paper }\end{array}$ \\
\hline
\end{tabular}

The results of mpRT-PCR were in agreement with those of ELISA for all PVX, PVM, PVY and PLRV samples tested.

PVS-specific primers were designed for mpRT-PCR diagnostic more thoroughly. When the first pair \#PVS-Forward and \#PVS-Reverse resulting in a fragment of $186 \mathrm{bp}$ was used for PVS detection, about one-third part of samples did not produced any bands although they were positive by ELISA. Full length of CP-coding sequences were established by another primer pair \#PVS-CP-Forward and \#PVS-CP-Reverse (table 1) of these samples after sequencing.

Thus, we found that the gRNA region 7547-7732 (186 bp) was variable for different isolates.

\section{Sequence analysis of different PVS isolates}

To verify the identity of the 14 different PVS isolates, the short DNA fragments of $186 \mathrm{bp}$ encoded the central part of CP were amplified and sequenced. The Kazakh samples were sequenced using primers \#PVS-Forward and \#PVS-Reverse or \#PVS-CPForward and \#PVS-CP-Reverse (Table 1). Then their sequences were compared with those of thirty already known PVS isolates using resource NCBI GenBank. Genotypes of the most known isolates have been already described [5, 6, 20, 21].

Computer analysis based on pairwise identity was carried out to delineate each of Kazakh isolates to different genotypes according to three classifications offered by Cox and Jones [5], Salari et al. [22] and Lin et al. [6]. The nucleotide sequences of all samples were grouped by phylogenetic analysis using MEGA X program (Fig. 2). Undetected of any classification variants PVS-m KF011280 (China) clustered into subgroup O-I [6], Yunnan YN KC430335 (China) and 6M:11 KC86620 (Tanzania) into subgroup O-III, Cm KC818635 (China) and PVS-1 KF011279 (China) into O-IV, RL5 JX683388 (Colombia) into A-II.

The most of Kazakh variants were identified as Ordinary, while the isolates KZ13-08-04, KZ14-04-8K and KZ2-16i clustered with known Andean (subgroup A-II) strains. Six members (KZ5-15p, KZ1-6i, KZ10-86, KZ11-93, KZ12-96, KZ5-11p) were identified as genotype O-I. Three isolates (KZ1-10i, KZ13-08-43, KZ2-2i) were placed into subgroup O-III. The variants of the O-II subgroup were classified by the similarity of the genome into one group, nevertheless they had a significant evolutionary distance 
between each other. So, the variant KZ11-PVS has only 97\% homology with Q1 JX183954 (Chile) or with 6-2 AB364946 (Syria) and IdDef FJ813514 (US). The members of the subgroup O-IV were assigned to the same cluster, but the lack of sufficient nucleotide sequence identity (only 98\%) did not allow them to be grouped according to MEGA X program different algorithms.

Many Kazakh isolates had the unique features. The unique nucleotide substitutions of all samples did not result in amino acid changes except isolates RL5 JX683388 (Colombia) and PVS-HU1 HF571059 (Hungary). There were serine instead of proline in the first case; and arginine in place of glycine in the second case.

Genotypes of Kazakh isolates presumably could be similar to Chinese and Europe isolates as nearest territorial neighbors. Indeed, the variants clustered into genotypes O-I and O-III had high percentage of homology with isolates from China Yunnan YN KC430335 and PVS-m KF011280 (figure 2).

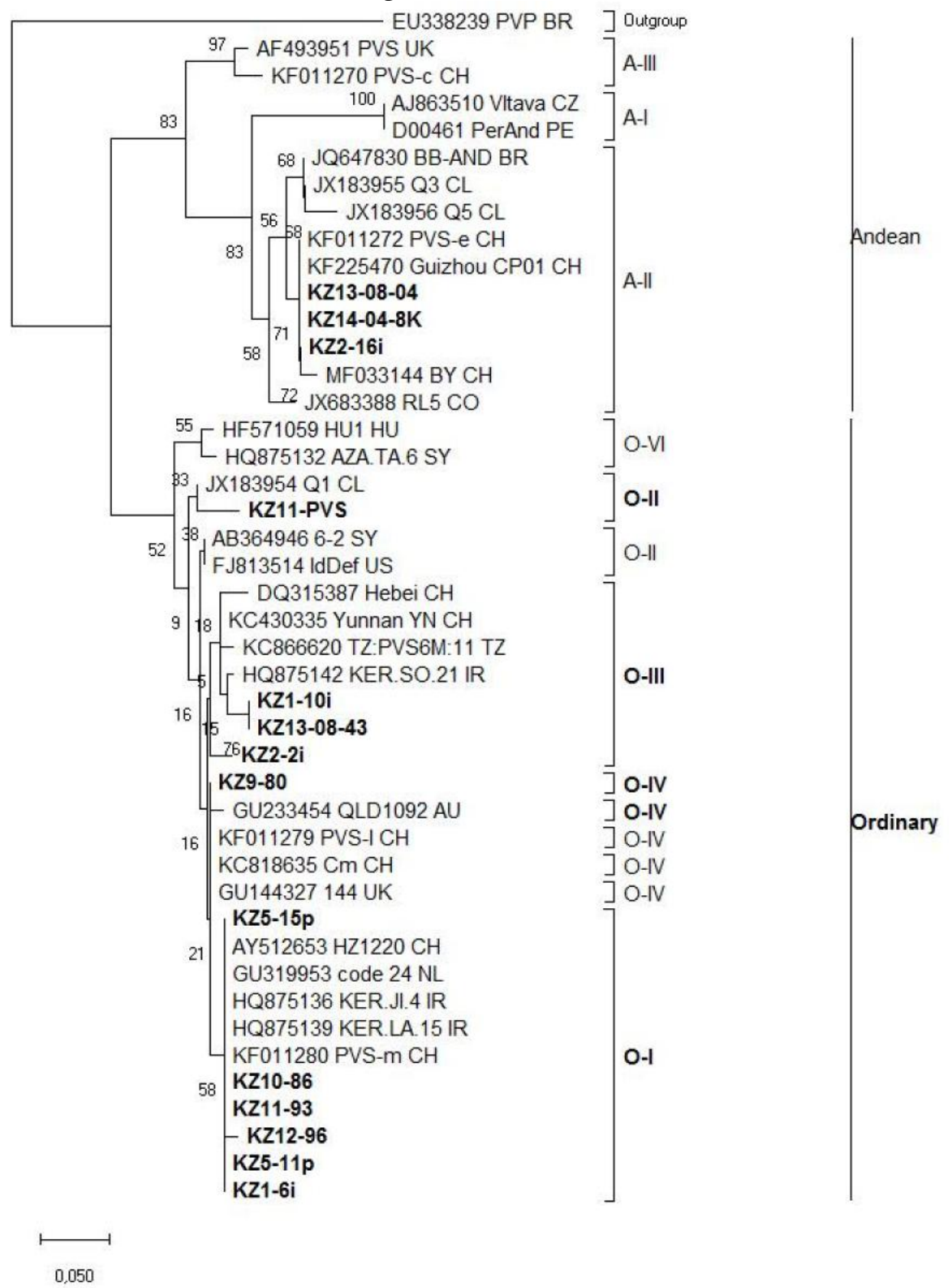

The percentage of replicate trees in which the associated taxa clustered together in the bootstrap test (2000 replicates) are shown next to the branches. An isolate potato virus P from Brazil was used as an outgroup. Kazakh isolates are shown in bold.

Fig. 2. Neighbor-Joining phylogenetic tree based on nucleotide sequences of coat protein central region of 44 potato virus $\mathrm{S}$ isolates. 
However, several variants of genotype A-II had high percentage of homology to such isolates as Q3 JX183955 (98\%) and RL5 JX683388 (96\%) from the most remote countries Chile and Columbia, respectively.

We made the conclusion about the existence of a wide variety of PVS strains with different origins.

\section{Diagnostics of different PVS strains by mpRT-PCR}

Several studies have been published on the diagnosis of various PVS strains previously [12, 13, 23, 24]. However, the nucleotide composition of the previously selected primers does not always allow to obtain a positive response when conducting mpRT-PCR for viruses isolated in another geographic region, due to the variability of the nucleotide sequences.

To achieve this goal, new primer pair \#PVS-new-Forward and \#PVS-newReverse (table 1) resulting in a fragment of $259 \mathrm{bp}$ was designed except the pair \#PVSForward and \#PVS-Reverse according sequencing results. Difference between Ordinary or Andean strains was observed when three primers \#PVS-Forward, \#PVS-newForward and \#PVS-new-Reverse were used in duplex or mpRT-PCR (Fig. 1, lanes 9, 10, 13, 15-19, 22 and 23). Kazakh isolates KZ13-08-04 (lane 22) and KZ2-16i (lane 23) were used as PVS ${ }^{\mathrm{A}}$ samples; KZ11-PVS (lane 13), KZ5-11p (lane 15), KZ2-2i (lane 16) - as $\mathrm{PVS}^{\mathrm{O}}$. For $\mathrm{PVS}^{\mathrm{O}}$ isolates the both bands of $169 \mathrm{bp}$ and $259 \mathrm{bp}$ or only short one were observed after duplex RT-PCR or multiplex reaction (lanes 9, 10, 13, 15-19), while for PVS ${ }^{\mathrm{A}}$ variants only one band of $259 \mathrm{bp}$ and faint trace of around $169 \mathrm{bp}$ were detected in the both cases (lanes 22 and 23).

These results demonstrate the feasibility of mpRT-PCR based on the specific primer design for detection of different PVS strains in a single step reaction and were confirmed on another 64 plant samples.

\section{CONCLUSION}

The wide diversity of Kazakh PVS isolates have unique features and some differences from each others and known variants was shown to what extent PVS genome has variability although amino acid sequence remains constant. The proposed method for diagnostic potato viruses allows to detect the presence of infection with great accuracy.

\section{Acknowledgements}

This research is supported by the Ministry of Education and Science, Republic of Kazakhstan (grant AP05131133 for 2018-2020)

\section{REFERENCES}

1. Hooker W.J. Compendium of potato diseases. APS Press: The American Phytopathological Society, 1981, 125p.

2. Matthews R. Plant Virology. New York and London: Academic Press; 1981, $916 \mathrm{p}$.

3. King A., Lefkowitz E., Adams M.J. Virus Taxonomy. Ninth Report of the International Committee on Taxonomy of Viruses. Elsevier, 2011,1338p. 
4. Nie X., Singh R. A novel usage of random primers for multiplex RT-PCR detection of virus and viroid in aphids, leaves, and tubers. Journal of Virological Methods, 2001, vol. 91, pp. 37-49. https://doi.org/10.1016/S0166-0934(00)00242-1

5. Cox B.A, Jones R.A. Genetic variability in the coat protein gene of Potato virus $\mathrm{S}$ isolates and distinguishing its biologically distinct strains. Archives of Virology, 2010, vol. 155, pp. 1163-1169. https://doi:10.1007/s00705-010-0680-6

6. Lin Y.-H., Abad J.A., Maroon-Lango C.J., Perry K.L., Pappu H.R. Molecular characterization of domestic and exotic potato virus $\mathrm{S}$ isolates and a global analysis of genomic sequences. Archives of Virology, 2014, vol. 159, pp. 2115-2122. https://doi:10.1007/s00705-014-2022-6

7. Dolby C., Jones R. Occurrence of the Andean strain of potato virus $\mathrm{S}$ in imported potato material and its effects on potato cultivars. Plant Pathology, 1987, vol. 36, pp.381-388. https://doi.org/10.1111/j.1365-3059.1987.tb02248.x

8. Foster G., Mills P. The 3'-nucleotide sequence of an ordinary strain of potato virus S. Virus Genes, 1992, vol. 6, pp. 213-220.

9. Matoušek J., Schubert J., Ptaček J., Kozlova P., Dedič P. Complete nucleotide sequence and molecular probing of potato virus S genome. Acta Virologica, 2005, vol. 49, pp. 195-205.

10. Morozov S., Solovyev A. Triple gene block: modular design of a multifunctional machine for plant virus movement. Journal of General Virology, 2003, vol. 84, pp. 1351-1366. DOI: 10.1099/vir.0.18922-0

11. Mackenzie D., Tremaine J., Stace-Smith R. Organization and interviral homologies of 3'-terminal portion of potato virus RNA. Journal of General Virology, 1989, vol. 70, pp. 1053-1063. doi: 10.1099/0022-1317-70-5-1053

12. Wang J., Meng F., Chen R., Liu J., Nie X., Nie B. RT-PCR differentiation, molecular and pathological characterization of Andean and ordinary strains of Potato virus $S$ in Potatoes in China. Plant Disease, 2016, vol. 100, pp. 1580-1585. http://dx.doi.org/10.1094/PDIS-11-15-1257-RE

13. Khassanov V.T., Vologin S.G. Occurrence of the Ordinary and the Andean Strains of Potato Virus $S$ Infecting Potatoes in the Eastern Region of Kazakhstan. Plant Disease, 2018, vol. 102, p. 2052. https://doi.org/10.1094/PDIS-12-17-2000-PDN

14. Kumar S., Stecher G., Li M., Knyaz C., Tamura K. MEGA X: Molecular Evolutionary Genetics Analysis across computing platforms. Molecular Biology and Evolution, 2018, vol. 35, pp. 1547-1549.

15. Saitou N., Nei M. The neighbor-joining method: A new method for reconstructing phylogenetic trees. Molecular Biology and Evolution, 1987, vol. 4, pp. 406-425. DOI: 10.1093/oxfordjournals.molbev.a040454

16. Felsenstein J. Confidence limits on phylogenies: An approach using the bootstrap. Evolution, 1985, vol. 39, pp. 783-791. DOI: 10.1111/j.15585646.1985.tb00420.x

17. Kimura M. A simple method for estimating evolutionary rate of base substitutions through comparative studies of nucleotide sequences. Journal of Molecular Evolution, 1980, vol. 16, pp. 111-120.

18. Askarova M., Manadilova A., Sadvakasova G., Kunaeva R., Lobenshtain G. Issledovanie kartofel'nyh polej Kazahstana na virusnoe zarazhenie [The study of potato fields in Kazakhstan for viral infection]. Biotehnologija. Teorija i praktika Biotechnology. Theory and practice, 1997, vol. 2, pp. 26-32.

19. Yekaterinskaya Y.M., Taykov V.V., Karpova O.V. Osobennosti leta krylatyh tlej na posadkah ozdorovlennogo kartofelja, vyrashhivaemogo v Kostanajskom NIISH [Peculiarities of volatile aphides flights at plantations of improved potato cultivated in Kostanay Agricultural Research Institute]. Zaschita kartofelya - Potato Protection, 2016, vol. 1, pp. 3-5. 
20. De Sousa Geraldino Duarte P., Galvino-Costa S.B., de Paula Ribeiro S.R., Figueira Ados R. Complete genome sequence of the first Andean strain of potato virus $S$ from Brazil and evidence of recombination between PVS strains. Archives of Virology, 2012, vol. 157, pp. 1357-1364. https://doi:10.1007/s00705-012-1289-8

21. Vallejo D.C., Gutierrez P.A.S., Marin M. Genome characterization of Potato virus S (PVS) variant from tuber sprouts of Solanum phureja Juz et Buk. Agronomia Colombiana, 2016, vol. 34, pp. 51-60. http://dx.doi.org/10.15446/agron.colomb.v34n1.53161

22. Salari K., Massumi H., Heydarnejad J., Hosseini Pour A., Varsani A. Analysis of Iranian Potato virus $\mathrm{S}$ isolates. Virus Genes, 2011 vol. 43, pp. 281-288. https://doi:10.1007/s11262-011-0619-3

23. Kushnarenko S., Romadanova N., Aralbayeva M., Zholamanova S., Alexandrova A., Karpova O. Combined ribavirin treatment and cryotherapy for efficient Potato virus $\mathrm{M}$ and Potato virus $\mathrm{S}$ eradication in potato (Solanum tuberosum L.) in vitro shoots. In Vitro Cellular and Developmental Biology - Plant, 2017, vol. 53, pp. 425432. DOI: $10.1007 / \mathrm{s} 11627-017-9839-0$

24. Matoušek J., Schubert J., Didic P. A broad variability of potato S carlavirus (PVS) revealed by analysis of RT-PCR-amplified virus sequences. Canadian Journal of Plant Pathology, 2000, vol. 22, pp. 29-37. https://doi.org/10.1080/07060660009501158

\title{
ҚАЗАҚСТАНДАҒЫ КАРТОПТ ВИРУСТАРЫН ДИАГНОСТИКАЛАУ ЖӘНЕ КАРТОПТЫН S ВИРУСЫНЫН ҚАЗАҚСТАНДЫК ИЗОЛЯТТАРЫНА МОЛЕКУЛАЛЫҚ СИПАТТАМА
}

\author{
Карпова О.В. ${ }^{1}$, Александрова А.М. ${ }^{1}$, Наргилова P.М. ${ }^{1}$, Крылдаков P.В. ${ }^{1}$, \\ Екатеринская Е.М. ${ }^{2}$, Ромаданова Н.В. ${ }^{3}$, Кушнаренко С.В. ${ }^{3}$, Искаков Б.К. \\ ${ }^{1}$ М.Ә. Айтхожин атындавы молекулалық биология және биохимия \\ институты, Досмухамедов көшесі 80, Алматы, 01000, Қазақстан \\ ${ }^{2}$ А.Байтұрсынов атындавы Қостанай мемлекеттік университеті, \\ Байтұрсынов көшесі, 47, Қостанай, 110005, Қазақсттан \\ ${ }^{3}$ Өсімдіктер биологиясы жсне биотехнологиясы институты, \\ Тимирязева көшесі, 45, Алматы, 050040, Қазақустан \\ oxkarpova@mail.ru
}

\section{ТУЙІН}

Қазақстандағы картоп дақылының өсу өнімділігі төмен болу себептерінің бірі- вирустармен зақымдалуы. Вирус инфекциясынан өсімдікті қорғау үшін қолданылатын ең тиімді шара- тұқымдық материалды сауықтырудың заманауи тәсілдерімен диагностика тәсілдерімен байланыстыру болып табылады. Қазақстанның Алматы және Қостанай облыстарынан алынған картоп өсімдіктерінің үлгілерімен ИФА және мультиплексті КТ-ПТР арқылы белгілі вирустар М, S, Y, X және картоп жапырағының ширатылу вирусы бар болуын анықтайтын талдаулар өткізілді. Соңғы жиырма жылдың ішінде егістіктегі вирус спектрі түбегейлі өзгергені анықталды. Қазіргі уақытта ең көп тараған Carlavirus туысының түрлері болып табылады. Талдаудан өткен үлгілердің 84.3\% картоптың М вирусына және өсімдіктердің $46.6 \%$ - картоптың $S$ вирусына шалдыққан. Көбіне көп санды инфекция жағдайлары тіркелген. Әртүрлі вирустар түрлерін ғана емес, картоп S вирусының әртүрлі штаммдарын анықтау 
мақсатында мультиплексті кері транскрипция рекциясының әдісі сондай-ақ, оған жұптасқан полимеразды реакция әдісі де оңтайландырылды. Вирус капсидінің ақуызын кодтайтын тізбектің ортаңғы бөлігін секвенирлеу реакциясының нәтижесінде $S$ вирусының қазақстандық он төрт өкілдерінің ішінде 11 Ordinary штаммына және қалған 3 Andian штаммына жаткызылды. Республика аумағында картоп S вирусы штаммдарының ауқымды әртүрлілігі және жан-жақты шығу тегі жөнінде қорытынды жасалынды. PCR.

Негізгі сөздер: картоп, Carlavirus, картоп S вирусы, капсид ақуызы, RT-

\section{ДИАГНОСТИКА ВИРУСОВ КАРТОФЕЛЯ В КАЗАХСТАНЕ И МОЛЕКУЛЯРНАЯ ХАРАКТЕРИСТИКА КАЗАХСТАНСКИХ ИЗОЛЯТОВ М ВИРУСА КАРТОФЕЛЯ}

Карпова О.В. ${ }^{1}$, Александрова А.М. ${ }^{1}$, Наргилова Р.М. ${ }^{1}$, Крылдаков Р.В. ${ }^{1}$, Екатеринская E.M. ${ }^{2}$, Ромаданова Н.В. ${ }^{3}$, Кушнаренко С.В. ${ }^{3}$, Искаков Б.К. $^{1}$

${ }^{1}$ Институт молекулярной биологии и биохимии им М.А. Айтхожина, ул. Досмухамедова, 80, Алмать, 01000, Казахстан

${ }^{2}$ Костанайский Государственный Университет им. А.Байтурсынова, ул.Байтурсынова, 47, Костанай, 110005, Казахстан

${ }^{3}$ Институт растительной биологии и биотехнологии, ул.Тимирязева, 45, Алматы, 050040, Казахстан

oxkarpova@mail.ru

\section{АБСТРАКТ}

Одна из причин низкой урожайности картофеля в Казахстане поражение вирусами. Наиболее эффективной мерой защиты растений от вирусной инфекции является сочетание современных методов оздоровления посадочного материала с методами диагностики. С помощью ИФА и мультиплексной РОТ-ПЦР проведен анализ на присутствие известных вирусов картофеля $\mathrm{M}, \mathrm{S}, \mathrm{Y}, \mathrm{X}$ и вируса скручивания листьев картофеля $\mathbf{y}$ образцов, полученных из Алматинской и Костанайской областей Казахстана. Обнаружено, что вирусный спектр на полях очень сильно изменился за последние двадцать лет. Наиболее распространенными в настоящее время оказались представители рода Carlavirus. 84.3\% образцов, прошедших анализ, были заражены М вирусом картофеля и $46.6 \%$ растений $-\mathrm{S}$ вирусом картофеля. В основном зарегистрированы случаи множественной инфекции. Проведена оптимизация метода мультиплексной реакции обратно транскрипции и сопряженной полимеразной реакции с целью диагностики не только различных вирусов, но и различных штаммов $S$ вируса картофеля. В результате реакции секвенирования центрального района кодирующей последовательности белка оболочки из четырнадцати казахстанских изолятов $S$ вируса 11 отнесены к штамму Ordinary и 3 - к штаммy Andian. Сделано заключение о существовании на территории республики широкого разнообразия штаммов $S$ вируса картофеля и показано их различное происхождение.

Ключевые слова: Картофель, Carlavirus, S вирус картофеля, белок оболочки, RT-PCR. 